\title{
INTERNATIONAL CONFERENCE ON ENTREPRENEURIAL COMPETENCIES IN A CHANGING WORLD (ECCW 2020)
}

$19^{\text {th }}$ November 2020

České Budějovice, Czech Republic
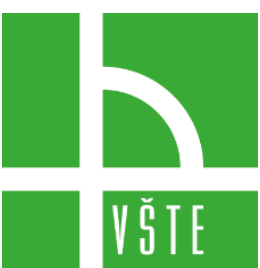

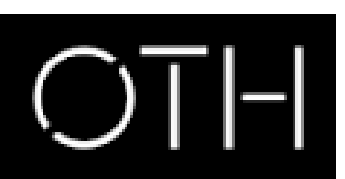

REGENSBURG

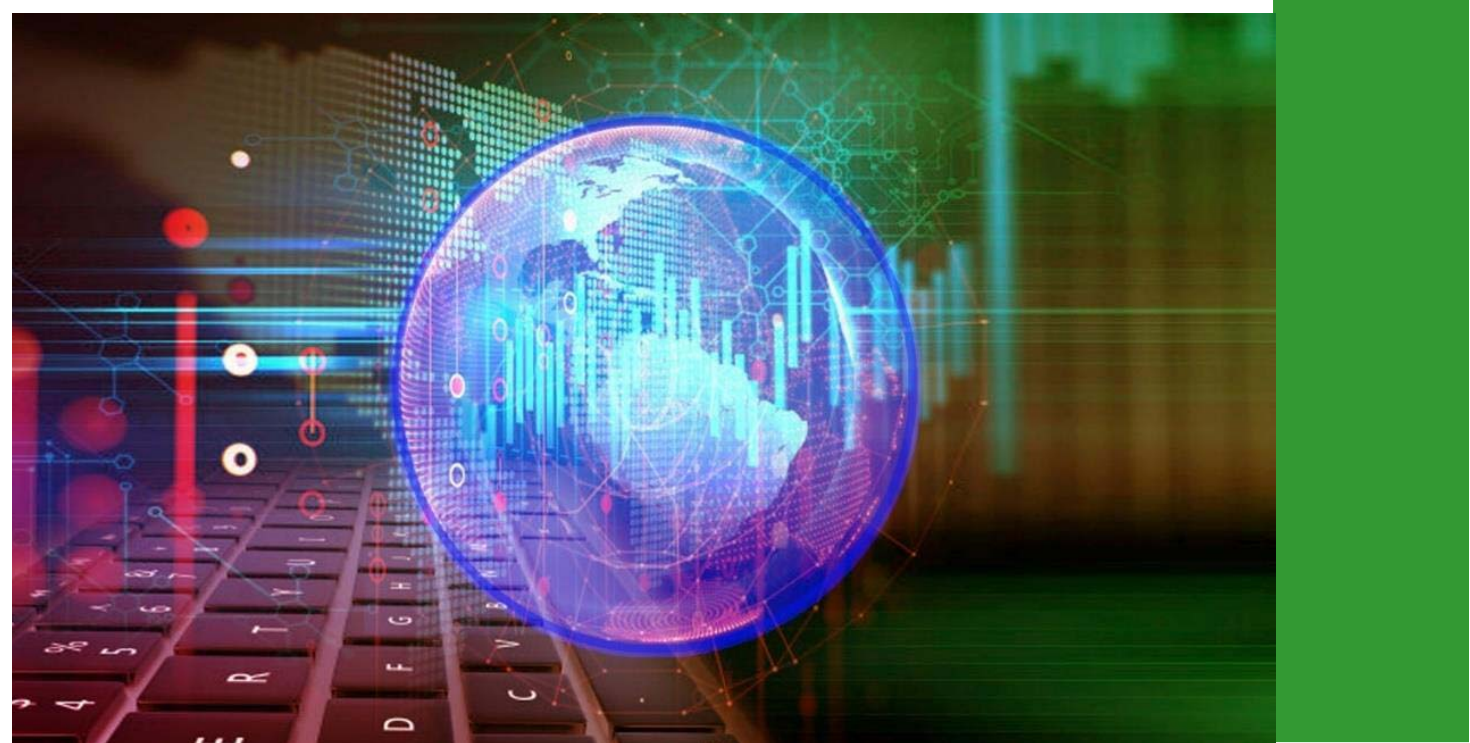




\section{International Conference}

on Entrepreneurial

Competencies

in a Changing World

(ECCW 2020)

http://www.podnikatelskekompetence.cz/

Editors: Zdeněk Caha, Michal Ruschak, Vendula Velková 


\section{About the conference ECCW 2020}

\section{Date of the conference: $19^{\text {th }}$ November 2020}

The conference is organized within the project Stabilization and Development of SMEs in Rural Areas (TL01000349) which is supported by the Technology Agency of the Czech Republic.

\section{Target}

The theme of the international conference is the stabilization and development of small and medium-sized enterprises in rural areas. The aim of the conference is to gather and discuss innovative ideas contributing to the development of this field at the European level with the help of scientists and practitioners. At the same time, to present specific measures applicable in the conditions of the Czech Republic.

\section{Thematic Areas}

\section{Section 1: Stabilization and development of SMEs in rural areas}

- Economic - financial management and administration

- Strategic management and decision making

- Human Resources SMEs

- Rural environment and SMEs

- Innovation

- Legislative-legal area

- Marketing as a tool for increasing the competitiveness of the company

Section 2: Support for start-up entrepreneurs and current trends strengthening the competitiveness of business entities

- Start-ups

- Business incubators and accelerators

- Corporate social responsibility

- Business ethics 


\section{About organizers \\ Institute of Technology and Business in České Budějovice}

Website: http://www.vstecb.cz/en/

Institute of Technology and Business (VŠTE) has about 4,500 students of technically and economically-oriented study programmes, two Master's and six Bachelor's study programmes with a wide range of specializations in civil engineering, mechanical engineering, transport and logistics and economics. Moreover, there are about 2,000 participants in lifelong learning, who officially do not have the status of "student, but it is one of the important activities of the school. This way it is possible to study two-year programmes of the European Council of Business Administration, MBA in Financial Management and BBA in Business Valuation. VŠTE is a higher education establishment with large project activities the main goal of which is to fulfil the long-term intentions of the Institute. The Institute is currently focused on systematic and permanent improvements in quality, deepening the cooperation with the application sphere, infrastructure development, transferring research activities into the application sphere, and increasing the employability of graduates. The Institute's project activities have significantly increased over the past two years.

Faculties

- Faculty of Corporate Strategy

- Faculty of Technology

- School of Expertness and Valuation

\section{Ostbayerische Technische Hochschule Regensburg}

Website: https://www.oth-regensburg.de/en.html

Ostbayerische Technische Hochschule Regensburg (OTH Regensburg) offers its students an excellent basis for a successful career. The technical university of applied sciences has around 11,000 students. 50 practiceoriented bachelor and master degree programmes in engineering, business studies, design, architecture, health and social studies offer high quality teaching and research. Modern facilities, such as 120 state-of- the- 
art laboratories and an award-winning library located on an attractive campus provide the basis for successful studies. OTH Regensburg's areas of expertise are energy \& mobility, information \& communication, life sciences $\&$ ethics, production \& systems and building \& infrastructure. These areas are tied together by expertise in sensor technology and digitalization. Cooperative applied research spans fields such as renewable energy, sensor technology, mechatronics, bioengineering, computer sciences and automotive engineering.

Faculties

- Applied Natural Sciences and Cultural Studies

- Architecture

- Civil Engineering

- Business Studies

- Electrical Engineering and Information Technology

- Computer Science and Mathematics

- Mechanical Engineering

- Social and Health Care Sciences

\section{Guaranteed by}

PaedDr. Mgr. Zdeněk Caha, Ph.D., MBA, MSc.

Prof. Dr. Sean Patrick Sassmannshausen

Prof. Ing. Marek Vochozka, MBA, Ph.D.

\section{Scientific Committee}

Prof. Ing. Marek Vochozka, MBA, Ph.D.

Institute of Technology and Business in České Budějovice (CZ)

PaedDr. Mgr. Zdeněk Caha, Ph.D., MBA, MSc.

Institute of Technology and Business in České Budějovice, Faculty of Corporate Strategy (CZ)

Prof. Dr. Sean Patrick Sassmannshausen

Ostbayerische Technische Hochschule Regensburg (DE) 
Prof. Kevin P. Kearns, Ph.D.

University of Pittsburgh (USA)

Prof. Ing. Jan Váchal, CSc.

Institute of Technology and Business in České Budějovice (CZ)

Dr. Thomas Elliot

Luxembourg Institute of Science and Technology (LUX)

Dr. Xenia Justus

Ostbayerische Technische Hochschule Regensburg (DE)

Doc. Mehmet A. Orhan, $\mathrm{PhD}, \mathrm{MSc}$, MBA

PSB Paris School of Business (F)

Prof. John Anchor

University of Huddersfield (UK)

Prof. Dr. József Poór, DSc.

Szent István University (HUN)

Prof. Dr. Daniel Kleber, M.A., M.Sc., M.A.

MODUL University Dubai (United Arab Emirates)

Prof. dr. Vilmantė Kumpikaitè-Valiūnienè

School of Economics and Management, Kaunas University of Technology (LTU)

Prof. Ing. Zuzana Dvořáková, CSc.

University of Chemistry and Technology Prague (CZ)

Dr. hab. Włodzimierz Sroka, prof. AWSB

WSB University, Faculty of Applied Sciences, Dąbrowa Górnicza (PL)

Assoc. prof. Ing. Miloš Hitka, $\mathrm{PhD}$.

Technical University Zvolen (SK) 
Dr. Marina Shavrovskaya

Ural State University of Economics (RUS)

Mario Bogdanović, $\mathrm{PhD}$, Senior research associate, College professor, MSc in Economics \& MA in Economics, MA in Psychology

(Istrian University of Applied Sciences in Pula, Croatia (HRV)

Dr. Anastasiya Pesha

Ural State University of Economics (RUS)

Johann Fabian Faltermeier, MBA

Ibi research an der Universität Regensburg GmbH (DE)

Dr. Koropets Olga

Ural Federal University (RUS)

Assoc. prof. PhDr. Ing. Ladislav Mura, $\mathrm{PhD}$.

J. Selye University (SK)

Doc. Mgr. Jakub Soviar, PhD.

University of Žilina (SK)

Assoc. prof. Ing. Jiří Dušek, Ph.D.

The College of European and Regional Studies (CZ)

Prof. Ing. Alžbeta Kucharčíková, PhD.

University of Zilina (SK)

Assoc. prof. Ing. Jarmila Straková, Ph.D.

Institute of Technology and Business in České Budějovice (CZ)

Ing. Petra Pártlová, Ph.D.

Institute of Technology and Business in České Budějovice (CZ)

Ing. Marcel Kordoš, PhD.

Alexander Dubček University of Trenčín (SK) 
Ing. Silvia Lorincová, $\mathrm{PhD}$.

Technical University Zvolen (SK)

Doc. PhDr. Dagmar Weberová, Ph.D. MBA

Tomas Bata University in Zlín (CZ)

Ing. Jaromír Vrbka, MBA, PhD.

Institute of Technology and Business in České Budějovice (CZ)

Mgr. Petr Šuleř, PhD.

Institute of Technology and Business in České Budějovice (CZ)

Ing. Monika Březinová, Ph.D.

University of South Bohemia (CZ)

Ing. Tomáš Brabenec, Ph.D., LLM.

University of Economics, Prague (CZ)

\section{Organizing Committee}

Ing. Michal Ruschak, MBA

Ing. Vendula Velková

Ing. Petra Prášilová 